\title{
MIR429 wt Allele
}

National Cancer Institute

\section{Source}

National Cancer Institute. MIR429 wt Allele. NCI Thesaurus. Code C82196.

The human MIR429 wild-type allele is located in the vicinity of 1 p36.33 and is approximately 82 bases in length. This allele, which encodes MIR429 pre-miRNA, plays a role in the regulation of gene expression. Alteration in the expression of this gene is associated with development of breast cancer. 